\title{
Antioxidant Capacity and Tentative Identification of Polyphenolic Compounds of Cones of Selected Coniferous Species
}

\author{
Tamás HofMANN* - Eszter VISI-RAJCZI - Balázs BocZ- \\ Dániel BocZ - Levente ALBERT
}

Institute of Chemistry, Faculty of Forestry, University of Sopron, Sopron, Hungary

\begin{abstract}
The cones of coniferous species are a waste biomass byproduct that can be potentially utilized for a variety of purposes. One of the many application fields is the extraction of bioactive materials, particularly antioxidant polyphenols. Scientific literature on the antioxidant content of coniferous cones at different ripening stages is limited. In this study, we conducted a comparative analysis of the antioxidant content of selected taxa that are either common in Hungary or that have not yet been investigated in the scientific literature in any great detail (Cedrus atlantica, Larix decidua, Picea abies, Pinus mugo, Pinus nigra, Pinus sylvestris, Pinus wallichiana, Tsuga canadensis, Tsuga heterophylla, Chamaecyparis lawsoniana, Taxodium distichum, Thuja occidentalis, Metasequoia glyptostroboides, Thuja orientalis, Cryptomeria japonica, Cunninghamia lanceolata). A comparison of green, mature and opened cones was performed for the assigned taxa. Folin-Ciocâlteu total polyphenol content (TPC), ferric reducing antioxidant power (FRAP) and 2,2-diphenyl-1-picrylhydrazyl (DPPH) assays were used to assess the antioxidant contents. Overall antioxidant power was determined by a scoring system that combined the three assay results. In general, best values were found for green cones, followed by mature, and opened cones for each taxon. Tsuga canadensis, Metasequoia glyptostroboides, Chamaecyparis lawsoniana, Cryptomeria japonica, Thuja orientalis and Picea abies all contained high amounts of antioxidants in both green and mature cones and attained the highest scores. High-performance liquid chromatographic/tandem mass spectrometric profiling of the cone polyphenols was also completed for selected samples. Results provide a basis for future bioactivity testing of these samples.
\end{abstract}

coniferous species / cones / antioxidants / HPLC-MS/MS

Kivonat - Túlevelü taxonok tobozainak antioxidáns kapacitása és polifenolos vegyületeinek vizsgálata. A tülevelü fajok tobozai olyan hulladék biomasszát képviselnek, melyeket többféle célra is lehetne használni. Az egyik ilyen felhasználási terület a bioaktív anyagok, például antioxidáns polifenolok kinyerése. A tobozérés különböző fenofázisaiban az antioxidáns tartalomra vonatkozó szakirodalmi adatok hiányosak. Jelen cikkben olyan taxonok vizsgálatát végeztük el, melyek vagy Magyarországon gyakoriak, vagy még nem történt meg a vizsgálatuk (Cedrus atlantica, Larix decidua, Picea abies, Pinus mugo, Pinus nigra, Pinus sylvestris, Pinus wallichiana, Tsuga canadensis, Tsuga heterophylla, Chamaecyparis lawsoniana, Taxodium distichum, Thuja occidentalis, Metasequoia glyptostroboides, Thuja orientalis, Cryptomeria japonica, Cunninghamia lanceolata). Elvégeztük a zöld, érett és lehullott tobozok összehasonlító vizsgálatát az összes polifenol tartalom (Folin-Ciocâlteu), a FRAP (ferric reducing antioxidant power) és a DPPH (2,2-diphenyl-1-picrylhydrazyl) antioxidáns kapacitás meghatározási módszerek segítségével. Az összesített antioxidáns kapacitás kiértékelése a

\footnotetext{
* Corresponding author: hofmann.tamas@uni-sopron.hu; H-9400 SOPRON, Bajcsy-Zs. u. 4, Hungary
} 
három módszer egyesítésével, egy pontrendszer segítségével történt meg. Összességében a legnagyobb antioxidáns kapacitást a zöld tobozokra mértük, a legalacsonyabbat a lehullott tobozokra mindegyik taxon esetében. A legmagasabb pontszámot a Tsuga canadensis, Metasequoia glyptostroboides, Chamaecyparis lawsoniana, Cryptomeria japonica, Thuja orientalis és Picea abies zöld és értett tobozai kapták. A kiválasztott minták esetében elvégeztük a polifenol készlet profilozását nagyhatékonyságú folyadékkromatográfiás/tandem tömegspektrometriás eljárással. Az eredmények alapját képezhetik ezen minták bioaktivitás-vizsgálatának.

\section{tülevelü fajok / toboz / antioxidansok / HPLC-MS/MS}

\section{INTRODUCTION}

Forestry, logging and timber production wastes (e.g. leaves, wood bark, cones, etc.) can be a rich source of antioxidant compounds (Dedrie et al. 2015, Bouras et al. 2016) with potential utilization fields including the production of healthcare-related products (Packer et al. 1999, Dzialo et al. 2016, Watson et al. 2018), natural food preservatives and ingredients (Coté et al. 2011, Gyawali - Ibrahim 2014, Kobus-Cisowska et al. 2014, Frydman et al. 2005), natural growth bioregulators (Popa et al. 2008, Vyvyan 2002) as well as silver nanoparticles (Fahimirada et al. 2019, Rolim et al. 2019) to name but a few.

As waste biomass basic materials, cones represent a biomass exclusively born by coniferous trees and shrubs belonging to one of the over 615 living species (Auders - Spicer 2012). Conifers bear "seed-cones" and "pollen-cones" out of which the female seed-cones are simply referred to as "cones"; these were the exclusive subject of the present study.

The primary use of forest tree cones has been seed extraction for the production of forestry propagation material. In the Mediterranean region the edible seeds of stone pine cones (Pinus pinea L.) are one of the most important tree nuts (Kemerli-Kalbaran - Ozdemir 2019). The empty cones are usually burned (Aniszewska - Bereza 2014) in an uncompressed state or can be converted to briquettes (Gendek et al. 2018). The cones Juniperus spp. have traditionally been used for flavouring purposes (Lesjak et al. 2011), while the cone extracts and essential oils of Pinus, Thuya, and Cedrus spp. have been used by traditional medicine for various beneficial (e.g. anti-inflammatory, antioxidant, antiseptic, antifungal, antimicrobial, analgesic etc.) health effects (Watanabe et al. 1995, Lesjak et al. 2011, Süntar et al. 2012, Djouahri et al. 2014). The cone extracts of Pinus parviflora Siebold et Zucc. were shown to be very powerful against HIV and influenza viruses (Nagata et al. 1990) and were also shown to possess significant antimutagenic and anticancer effects (Nagasawa et al. 1992). The cone and essential oil extracts of Metasequoia glyptostroboides (Bajpai et al. 2014), Juniperus sibirica Burgsdorf. (Lesjak et al., 2011), Tetraclinis articulata (Vahl) Mast. (Djouahri et al. 2014), Cupressus sempervirens var. pyramidalis (L.) (Tumen et al. 2012) and of Pinus spp. (Süntar et al. 2012, Bradley et al. 2014, Tümen et al. 2018, Wang et al. 2019) were recently shown to have significant beneficial effects on human health. The latest results indicate that pine cone and pine cone extracts can be used for their various useful properties, e.g. being a source as dietary fibre (Kartal - Ozturk 2016), or starting materials for the production of coagulants (Hussain et al. 2019) and adsorbents (Kupeta et al. 2018, Mtshatsheni et al. 2019).

Despite the listed results, the literature lacks systematic research of the antioxidant composition of cones and the assessment of their role as a source of natural antioxidants. Moreover, sample collection times in the presented examples - more specifically, the phenophase of cone maturity - have rarely been documented in the literature. Recently Hofmann et al. (2020) concluded a systematic research using optimized extraction conditions and multiassay evaluation for the assessment of the antioxidant content of coniferous cones while respecting the phenophase of cone maturity; however, this study included only 6 taxa. 
The aim of the present research was to extend previous studies (Hofmann et al. 2020) by investigating altogether 16 taxa including Atlas cedar (Cedrus atlantica Endl.), European larch (Larix decidua Mill.), Norway spruce (Picea abies H. Karst.), mountain pine (Pinus mugo Turra), black pine (Pinus nigra J.F. Arnold), Scots pine (Pinus sylvestris L.), Himalayan pine (Pinus wallichiana A. B. Jacks.), eastern hemlock (Tsuga canadensis (L.) Carrière), western hemlock (Tsuga heterophylla (Raf.) Sarg.), Lawson cypress (Chamaecyparis lawsoniana (A. Murray) Parl.), bald cypress (Taxodium distichum (L.) Rich.), northern white-cedar (Thuja occidentalis L.), dawn redwood (Metasequoia glyptostroboides Hu and W. C. Cheng), Chinese arborvitae (Thuja orientalis L.), Japanese cedar (Cryptomeria japonica (L.f.) D. Don) and China fir (Cunninghamia lanceolate (Lamb.) Hook).

Antioxidant properties were assayed by the Folin-Ciocâlteu total polyphenol content (TPC), ferric reducing antioxidant power (FRAP) and 2,2-diphenyl-1-picrylhydrazyl (DPPH) methods. The evaluation of the overall antioxidant power was accomplished by a scoring system, which combined the results of the TPC, FRAP, and DPPH methods. In this manner a comprehensive evaluation of the results between various samples with potentially different antioxidant compositions was achieved.

The polyphenol profile of most relevant samples with the highest antioxidant potential was also investigated using high-performance liquid chromatography/multistage mass spectrometry (HPLC-MS/MS) in order to identify the structure of major antioxidant compounds, primarily polyphenols.

\section{MATERIALS AND METHODS}

\subsection{Chemicals and reagents}

Double distilled water was prepared for the extractions using conventional distillation equipment. LCMS grade acetonitrile, and acetone was obtained from VWR International (Budapest, Hungary). Gallic acid, ascorbic acid, DPPH, 2,4,6-tripyridyl-S-triazine (TPTZ), iron(III)-chloride, acetic acid, sodium acetate, hydrochloric acid, and sodium carbonate were obtained from Sigma-Aldrich (Budapest, Hungary). Folin-Ciocâlteu reagent was purchased from Merck (Darmstadt, Germany).

\subsection{Sample collection and extraction}

Sample collection occurred at the Botanical Garden of the University of Sopron in Sopron, Hungary between July-October 2019. Three ripening stages were sampled: green cones (collected in July when cones are green, yet nearly at their full size at the final year of maturation), mature cones (collected in August/September when the cones turned brown in colour and scales began to open) and opened cones (taken in September/October, at a fully opened state having released their seeds and found on trees or to the ground). One healthy individual of each taxon was sampled by collecting a minimum of 10 cones from different parts of the crown at each sampling occasion. Cone samples were put into sealed plastic bags and stored at $-20^{\circ} \mathrm{C}$ until processing. Prior to extraction, samples were thawed and ground. Ultrasonic extraction was performed using an Elma Transsonic T570 ultrasonic bath (Elma Schmidbauer GmbH, Singen, Germany) as follows: 0.45 g ground sample was homogenized with $45 \mathrm{ml}$ acetone:water $80: 20 \mathrm{v} / \mathrm{v}$ in a $50 \mathrm{ml}$ centrifuge tube and sonicated for $3 \mathrm{x} 10 \mathrm{~min}$ as described by Hofmann et al. (2020). One extraction was conducted for each sample. 


\subsection{Determination of antioxidant properties}

TPC, FRAP, and DPPH measurements were run in triplicates using of a Hitachi U-1500 type spectrophotometer (Hitachi Ltd., Tokyo, Japan).

\subsubsection{Total polyphenol content (TPC)}

TPC determination was completed by applying the Folin-Ciocâlteu assay (Singleton - Rossi 1965) using gallic acid as the standard: $0.5 \mathrm{ml}$ extract solution was mixed with $2.5 \mathrm{ml} 10$-fold diluted Folin-Ciocâlteu reagent. After $1 \mathrm{~min}, 2 \mathrm{ml} 0.7 \mathrm{M} \mathrm{Na}_{2} \mathrm{CO}_{3}$ solution was added and the reaction mixture was heated for $5 \mathrm{~min}$ in a $50{ }^{\circ} \mathrm{C}$ water bath. Reaction was stopped by cooling to room temperature in a cold water bath. Solution absorbance was measured at $760 \mathrm{~nm}$. The results were expressed as mg equivalents of gallic acid/g dry bark units (mg GAE/g d.w.).

\subsubsection{FRAP antioxidant capacity}

The method described by Benzie - Strain (1996) was applied for the measurement of the FRAP antioxidant capacity at $593 \mathrm{~nm}$ using ascorbic acid as a standard. FRAP reagent was prepared as follows: $25 \mathrm{ml}$ of $10 \mathrm{mM}$ TPTZ solution (aqueous with $84 \mu \mathrm{cc} . \mathrm{HCl}$ ) was mixed with 250 $\mathrm{ml}$ of acetate buffer ( $300 \mathrm{mM}, \mathrm{pH} 3.6)$ and $25 \mathrm{~mL}$ of $20 \mathrm{mM}$ aqueous $\mathrm{FeCl}_{3}$ solution. Fifty $\mu 1$ sample was mixed with $1500 \mu \mathrm{l}$ FRAP reagent in glass test tubes at ambient temperature and after 5 min reaction time absorbance was measured. Results were given in mg equivalents of ascorbic acid/g dry weight (mg AAE/g dw.).

\subsubsection{DPPH antioxidant capacity}

The slightly modified method of Sharma - Bhat (2009) was used for running the DPPH assay as follows: $2090 \mu \mathrm{l}$ unbuffered methanol was mixed with $900 \mu 12 \times 10^{-4} \mathrm{M}$ methanolic DPPH solution and $10 \mu \mathrm{l}$ extract. After $30 \mathrm{~min}$ incubation at room temperature in the dark, the decrease in absorbance was determined at $515 \mathrm{~nm}$. Results were calculated in $\mathrm{IC}_{50}$ (50\% inhibition concentration) values in $\mu \mathrm{g}$ extractives $/ \mathrm{ml}$ assay $(\mu \mathrm{g} / \mathrm{ml})$ units, representing the amount of extractives which will react with $50 \%$ of the added $\mathrm{DPPH} \bullet$ radicals in the total assay volume (3 $\mathrm{ml})$.

\subsection{HPLC-MS/MS analyses}

Separation of the cone extracts of Norway spruce and eastern hemlock was achieved using a Shimadzu LC-20 type high-performance liquid chromatograph coupled with a Shimadzu SPDM20A type diode array detector (PDA) (Shimadzu Corporation, Kyoto, Japan) and an AB Sciex 3200 QTrap triple quadrupole/linear ion trap mass spectrometric (MS) detector (AB Sciex, Framingham, USA). A Phenomenex Synergy Fusion-RP 80A, $250 \mathrm{~mm}$ x $4.6 \mathrm{~mm}, 4 \mu \mathrm{m}$ column was used for the separation with a Phenomenex SecurityGuard ULTRA LC type guard column (Phenomenex Inc., Torrance, USA) at $40^{\circ} \mathrm{C}$. The injection volume was $15 \mu 1$. The binary gradient of $\mathrm{A}\left(\mathrm{H}_{2} \mathrm{O}+0.1 \% \mathrm{HCOOH}\right)$ and $\mathrm{B}\left(\mathrm{CH}_{3} \mathrm{CN}+0.1 \% \mathrm{HCOOH}\right)$ solvents was run with $1.2 \mathrm{ml} / \mathrm{min}$ flow-rate using the following time gradient: $3 \% \mathrm{~B}(0-4 \mathrm{~min}), 6 \% \mathrm{~B}$ (10 $\mathrm{min}), 20 \%$ B (34 min), 57\% B (73 min), 100\% B (90-98 min), 3\% B (99-106 min). The PDA detector signal $(250-380 \mathrm{~nm})$ was recorded to monitor separation of peaks. Negative electrospray ionization mode was used for the MS detector by allowing $0.6 \mathrm{~mL} / \mathrm{min}$ flow to enter the MS ion source using a split valve. Polyphenols were identified with the Information Dependent Analysis (IDA) scanning function of the mass spectrometer using a survey (Q1) scan between $150-1300 \mathrm{~m} / \mathrm{z}$ and respective dependent (Q3) product ion scans between $80-1300 \mathrm{~m} / \mathrm{z}$. Ion source settings were as follows: spray voltage: $-4500 \mathrm{~V}$, source temperature: $500^{\circ} \mathrm{C}$, curtain gas $\left(\mathrm{N}_{2}\right)$ pressure: $40 \mathrm{psi}$, spray gas $\left(\mathrm{N}_{2}\right)$ pressure: 30 psi, drying gas $\left(\mathrm{N}_{2}\right)$ pressure: $30 \mathrm{psi}$. Chromatographic data were acquired and evaluated using the Analyst 1.6.3 software. Mass 
spectra evaluation and compound identification was achieved using the RIKEN tandem mass spectral database (Sawada et al. 2012), via the scientific data found in the literature and by the use of fragmentation rules (McLafferty - Tureček 1993).

\subsection{Statistics}

In order to compare the respective antioxidant capacities of the extracts, ANOVA analysis was run using Statistica 11 (StatSoft Inc., Tulsa, USA) software with the Tukey HSD method.

\section{RESULTS AND DISCUSSION}

\subsection{Evaluation of the TPC, FRAP and DPPH results}

Table 1 includes the TPC, FRAP, and DPPH data of the samples indicating statistical comparison (ANOVA) for the 10 best results within each method. In all of the investigated taxa, the highest TPC was measured in green cone samples, followed by mature and opened cone samples. Overall the highest TPC was determined in the green cones of eastern hemlock (157.25 $\pm 9.98 \mathrm{mg}$ GAE/g dw.), Lawson cypress (131.68 $\pm 4.35 \mathrm{mg} \mathrm{GAE} / \mathrm{g} \mathrm{dw}$.), Japanese cedar (131.74 $\pm 3.00 \mathrm{mg}$ GAE/g dw.) and dawn redwood (113.60 $\pm 4.81 \mathrm{mg} \mathrm{GAE} / \mathrm{g} \mathrm{dw}$.$) .$ Respecting mature and opened cones highest TPC values were determined for dawn redwood (mature: $91.25 \pm 3.69 \mathrm{mg} \mathrm{GAE} / \mathrm{g} \mathrm{dw}$., opened: $60.16 \pm 8.23 \mathrm{mg} \mathrm{GAE} / \mathrm{g} \mathrm{dw}$.), Chinese arborvitae (mature: $81.22 \pm 5.30 \mathrm{mg} \mathrm{GAE} / \mathrm{g} \mathrm{dw}$., opened: $68.88 \pm 4.91 \mathrm{mg}$ GAE$/ \mathrm{g} \mathrm{dw}$.), Japanese cedar (mature: $74.18 \pm 2.09 \mathrm{mg} \mathrm{GAE} / \mathrm{g} \mathrm{dw}$., opened: $57.41 \pm 2.93 \mathrm{mg} \mathrm{GAE} / \mathrm{g} \mathrm{dw}$.) and Norway spruce (mature: $64.64 \pm 2.68 \mathrm{mg} \mathrm{GAE} / \mathrm{g} \mathrm{dw}$., opened: $46.39 \pm 3.54 \mathrm{mg} \mathrm{GAE} / \mathrm{g} \mathrm{dw}$.).

According to literature data, Hofmann et al. (2020) determined high TPC levels for Norway spruce and eastern hemlock green cone samples. Horiba et al. (2016) found $84.9 \pm 3.3 \mathrm{mg}$ GAE/g dw TPC in Japanese cedar cones (without seeds), which is comparable to the present results.

The overall highest TPC, determined for eastern hemlock green cones $(157.25 \pm 9.98 \mathrm{mg}$ $\mathrm{GAE} / \mathrm{g} \mathrm{dw}$.) was surprisingly higher than that of the related taxon, western hemlock $(89.16 \pm$ 5.51 GAE/g dw). In fact, Hernes - Hedges (2004) reported the tannin content of western hemlock cones to be $3.13 \mathrm{wt}$.\%; however, the authors did not document either the phenophase of cone maturity or the month of the sample collection. Hernes - Hedges (2004) also found that the bark and green needles contained more tannins compared to cones, yet did not investigate the amount of other types of polyphenols.

The limitation of the Folin-Ciocâltau assay (Singleton - Rossi 1965) is that it is known to interfere with other types of antioxidants (Prior et al. 2005, Everette et al. 2010). In fact, the TPC method is considered one of the $>100$ different assays currently used for the determination of antioxidant capacity and radical scavenging ability (Cornelli 2009). None of these assays is individually able to measure the total antioxidant power of all compounds in plant extracts. Therefore, the use of multiple assays to estimate the "overall" antioxidant potential of complex extracts is recommended (Ghiselli et al. 2000). The present study used the FRAP and the DPPH methods to provide further results on the antioxidant power of the samples. 
Table 1. TPC $1, F R A P^{2}$, and DPPH $H^{3}$ antioxidant capacity of the cones (mean \pm standard deviation). Different superscript letters indicate significant differences at $p<0.05$ (TPC, FRAP, DPPH) between the samples with the 10 best values

\begin{tabular}{|c|c|c|c|c|c|c|c|c|c|}
\hline & \multicolumn{3}{|c|}{ TPC (mg GAE/g dw.) } & \multicolumn{3}{|c|}{ FRAP (mg AAE/g dw.) } & \multicolumn{3}{|c|}{ DPPH IC ${ }_{50}(\mu \mathrm{g}$ extractives/ml) } \\
\hline & Green & Mature & Opened & Green & Mature & Opened & Green & Mature & Opened \\
\hline Atlas cedar & $88.41 \pm 1.68$ & $14.96 \pm 2.24$ & $7.46 \pm 0.26$ & $2.08 \pm 3.13^{\mathrm{a}}$ & $4.48 \pm 0.11$ & $3.37 \pm 0.10$ & $21.44 \pm 2.94$ & $88.82 \pm 12.86$ & $56.92 \pm 15.87$ \\
\hline European larch & $83.44 \pm 4.27$ & $25.98 \pm 0.94$ & $17.60 \pm 2.15$ & $55.96 \pm 0.93$ & $14.18 \pm 0.83$ & $4.09 \pm 0.17$ & $9.07 \pm 1.39$ & $12.53 \pm 0.38$ & $28.21 \pm 6.84$ \\
\hline Norway spruce & $105.58 \pm 7.92^{\mathrm{ab}}$ & $64.64 \pm 2.68$ & $46.39 \pm 3.54$ & $72.02 \pm 8.76^{\mathrm{ab}}$ & $50.19 \pm 2.08$ & $28.35 \pm 3.37$ & $10.75 \pm 0.32$ & $9.38 \pm 1.14$ & $8.57 \pm 0.17^{\mathrm{ab}}$ \\
\hline Mountain pine & $95.76 \pm 9.48^{\mathrm{a}}$ & $22.33 \pm 3.31$ & $15.96 \pm 1.10$ & $60.06 \pm 2.77$ & $9.34 \pm 0.07$ & $7.25 \pm 0.19$ & $7.87 \pm 0.31^{\mathrm{abc}}$ & $27.83 \pm 3.73$ & $18.86 \pm 0.14$ \\
\hline Black pine & $89.22 \pm 4.79$ & $19.70 \pm 3.36$ & $7.08 \pm 0.34$ & $58.21 \pm 2.34$ & $9.55 \pm 0.52$ & $4.50 \pm 0.17$ & $15.33 \pm 1.39$ & $45.90 \pm 2.69$ & $62.32 \pm 1.90$ \\
\hline Scots pine & $46.30 \pm 1.81$ & $18.99 \pm 1.44$ & $13.19 \pm 1.53$ & $33.42 \pm 3.12$ & $9.41 \pm 0.32$ & $7.26 \pm 0.14$ & $72.40 \pm 21.26$ & $29.32 \pm 1.10$ & $22.88 \pm 0.54$ \\
\hline Himalayan pine & $62.52 \pm 5.09$ & $17.76 \pm 1.35$ & $8.18 \pm 0.97$ & $38.84 \pm 0.69$ & $8.33 \pm 0.56$ & $3.85 \pm 0.21$ & $25.72 \pm 3.50$ & $54.76 \pm 14.54$ & $72.58 \pm 7.23$ \\
\hline Eastern hemlock & $157.25 \pm 9.98^{d}$ & $56.13 \pm 4.07$ & $10.57 \pm 1.69$ & $100.11 \pm 0.40^{\mathrm{e}}$ & $46.57 \pm 1.02$ & $5.94 \pm 0.25$ & $7.83 \pm 0.29^{\mathrm{abc}}$ & $11.37 \pm 0.67$ & $17.74 \pm 1.01$ \\
\hline Western hemlock & $89.16 \pm 5.51$ & $30.77 \pm 2.22$ & $10.01 \pm 1.77$ & $59.11 \pm 1.73$ & $31.03 \pm 1.55$ & $4.53 \pm 0.09$ & $11.16 \pm 1.37$ & $15.52 \pm 0.84$ & $40.44 \pm 17.94$ \\
\hline Lawson cypress & $131.68 \pm 4.35^{\mathrm{c}}$ & $20.61 \pm 2.27$ & $16.21 \pm 2.11$ & $89.42 \pm 6.82^{\text {cde }}$ & $9.18 \pm 0.12$ & $8.36 \pm 0.13$ & $7.23 \pm 0.41^{b c}$ & $22.46 \pm 1.72$ & $30.50 \pm 6.72$ \\
\hline Bald cypress & $70.99 \pm 4.49$ & $52.20 \pm 1.86$ & $29.53 \pm 3.96$ & $57.34 \pm 1.28$ & $49.69 \pm 5.07$ & $42.42 \pm 3.29$ & $8.45 \pm 0.74^{\mathrm{ab}}$ & $13.17 \pm 2.13$ & $13.42 \pm 0.60$ \\
\hline Northern white-cedar & $93.71 \pm 5.47^{\mathrm{a}}$ & $39.96 \pm 2.59$ & $31.38 \pm 2.57$ & $76.46 \pm 3.44^{\mathrm{abc}}$ & $49.81 \pm 0.11$ & $18.54 \pm 0.83$ & $9.93 \pm 0.62$ & $9.21 \pm 0.30$ & $8.13 \pm 0.55^{\mathrm{ab}}$ \\
\hline Dawn redwood & $113.60 \pm 4.81^{\mathrm{b}}$ & $91.25 \pm 3.69^{\mathrm{a}}$ & $60.16 \pm 8.23$ & $129.16 \pm 3.01^{\mathrm{f}}$ & $147.00 \pm 6.83^{\mathrm{g}}$ & $61.43 \pm 3.51$ & $6.22 \pm 0.42^{c}$ & $4.42 \pm 0.07^{\mathrm{d}}$ & $7.15 \pm 0.87^{b c}$ \\
\hline Chinese arborvitae & $106.67 \pm 2.76^{\mathrm{ab}}$ & $81.22 \pm 5.30$ & $68.88 \pm 4.91$ & $78.49 \pm 1.55^{\mathrm{bcd}}$ & $93.12 \pm 4.84^{\mathrm{de}}$ & $31.60 \pm 2.02$ & $9.56 \pm 0.50$ & $15.76 \pm 0.45$ & $17.27 \pm 7.71$ \\
\hline Japanese cedar & $131.74 \pm 3.00^{\mathrm{c}}$ & $74.18 \pm 2.09$ & $57.41 \pm 2.93$ & $60.87 \pm 5.21$ & $41.04 \pm 2.08$ & $24.16 \pm 0.86$ & $10.13 \pm 0.76$ & $10.55 \pm 1.40$ & $17.51 \pm 0.56$ \\
\hline China fir & $92.24 \pm 1.57^{\mathrm{a}}$ & $36.36 \pm 2.29$ & $35.94 \pm 1.33$ & $67.99 \pm 8.88^{\mathrm{ab}}$ & $37.20 \pm 2.68$ & $20.65 \pm 1.44$ & $9.03 \pm 1.19^{\mathrm{a}}$ & $13.79 \pm 0.46$ & $11.14 \pm 0.45$ \\
\hline
\end{tabular}

1: Total polyphenol content

2: Ferric reducing antioxidant power

3: 2,2-diphenyl-1-picrylhydrazyl 
Regarding FRAP results, green cone samples showed the best results in general. The only opposite tendency was observed with dawn redwood and Chinese arborvitae, where mature cones (D.r.: $147.00 \pm 6.83 \mathrm{mg} \mathrm{AAE} / \mathrm{g}$ dw., C.a: $93.12 \pm 4.84 \mathrm{mg} \mathrm{AAE} / \mathrm{g} \mathrm{dw}$.) had superior FRAP values compared to green cone results (D.r.: $129.16 \pm 3.01 \mathrm{mg} \mathrm{AAE} / \mathrm{g}$ dw., C.a: $78.49 \pm 1.55$ mg AAE/g dw.) showing excellent FRAP. Overall the best FRAP was determined for the green cones and opened cones of previous two taxa and for the green cones of eastern hemlock (100.11 $\pm 0.40 \mathrm{mg}$ AAE/g dw.). According to Lesjak et al. (2011, 2014), the FRAP of Juniperus spp. cones varies between $3.61 \pm 0.03 \mathrm{mg} \mathrm{AAE} / \mathrm{g} \mathrm{dw}$. (Juniperus macrocarpa Sibth. et Sm.) to $35.26 \pm 1.12 \mathrm{mg} \mathrm{AAE} / \mathrm{g} \mathrm{dw}$. (Juniperus sibirica Burgsdorf.), which also indicates that big differences between related taxa can exist, as is the case with eastern $(100.11 \pm 0.40 \mathrm{mg} \mathrm{AAE} / \mathrm{g}$ dw.) and western hemlock $(59.11 \pm 1.73 \mathrm{mg} \mathrm{AAE} / \mathrm{g} \mathrm{dw}$.) cones in the present study.

The DPPH radical scavenging activity was determined using the $\mathrm{IC}_{50}$ value $(50 \%$ inhibition concentration), with low $\mathrm{IC}_{50}$ indicating high antioxidant capacities. The DPPH results also showed the general decreasing tendency of the order green $>$ mature $>$ opened cones within a given taxon. The best results were obtained for the mature $(4.42 \pm 0.07 \mu \mathrm{g} / \mathrm{ml})$ and green $(6.22$ $\pm 0.42 \mu \mathrm{g} / \mathrm{ml})$ cones of dawn redwood, and for green cones of Lawson cypress $(7.23 \pm 0.41$ $\mu \mathrm{g} / \mathrm{ml})$ and eastern hemlock $(7.83 \pm 0.29 \mu \mathrm{g} / \mathrm{ml})$. In fact, the excellent DPPH activity (Bajpai et al. 2009, 2017) and bioactivity (Bajpai et al. 2007, 2009, Yoon et al. 2011) of dawn redwood cone extracts has already been reported in scientific literature.

The TPC, FRAP, and DPPH data makes it apparent that all of the three assays indicated different orders for the best results, which was attributed to the different compositions of the extracts as well as to the different working principle and selectivity of the assays (Apak et al. 2007, Müller et al. 2011).

In order to obtain a comprehensive measure of the overall antioxidant efficiency of the cone extracts and to consider the different selectivity of methods, the summarized evaluation of results of the three different methods was implemented.

\subsection{Combined evaluation of the TPC, FRAP and DPPH results}

Combined evaluation of the TPC, FRAP and DPPH was achieved using a scoring system (Hofmann et al. 2020) with the following calculation: For the TPC and FRAP results, 0 points were assigned to the weakest values and 1 to the best values within each assay, using linear approximation for the other values. In the case of DPPH assay, opposite scoring was used (lowest $\mathrm{IC}_{50}$ value, score: 1 ; the highest $\mathrm{IC}_{50}$, score: 0 ). The respective scores of TPC, FRAP and DPPH were then summarized for each sample to estimate the measure of the overall antioxidant efficiency (Table 2).

Regarding the sum of scores, the highest scores - those with the best overall antioxidant power - were determined in the green cones of eastern hemlock (2.63), dawn redwood (2.56), Lawson cypress (2.40), Japanese cedar (2.16), Chinese arborvitae (2.13) and Norway spruce (2.06) and for the mature cones of dawn redwood (2.56). Interestingly eastern hemlock contained much higher overall antioxidant power compared to related western hemlock for green, mature and opened cone samples, showing big differences between respective samples; this discrepancy requires further research to determine an explanation.

Of these taxa, the bioactivity, antioxidant activity, or uses of their cone extracts have already been reported in the literature for Lawson cypress (Smith et al., 2007, Kilinc et al. 2015), dawn redwood (Bajpai et al. 2007, 2009, 2014, 2017, Yoon et al. 2011), Japanese cedar (Horiba et al. 2016) and Chinese arborvitae (Yogesh - Ali 2014).

However, no data on the polyphenolic composition and bioactivity of Norway spruce and eastern hemlock cone extracts exists in the scientific literature. Norway spruce is one of the most widespread coniferous tree species in Europe, possessing significant ecological, industrial 
and economic significance (Meloni et al. 2007, Lamedica et al. 2011). Eastern hemlock is an ecologically important foundation species in forests of eastern North America (Clark et al. 2012) with a natural range extending from northern Georgia and Alabama to southern Canada and westward into the central Great Lakes states (McWillams - Schmidt 2000). Information on molecular cone extract composition will provide a basis for the future research on the role these compounds play in possible bioactivity effects. Hence, the remainder of this article will focus on the identification of cone extractives, especially polyphenolic compounds found in the green cone tissues of Norway spruce and eastern hemlock.

Table 2. Normalized values (scores) of the TPC $C^{1}, F R A P^{2}$, and DPPH IC $50^{3}$ values and the sum of scores for each sample representing the combined antioxidant values.

\begin{tabular}{|c|c|c|c|c|c|c|c|c|c|c|c|c|}
\hline & \multicolumn{3}{|c|}{$\mathrm{TPC}^{1}$} & \multicolumn{3}{|c|}{ FRAP $^{2}$} & \multicolumn{3}{|c|}{ DPPH $\mathrm{IC}_{50}{ }^{3}$} & \multicolumn{3}{|c|}{ Sum of scores } \\
\hline & Gr. & Mat. & Op. & Gr. & Mat. & Op. & Gr. & Mat. & Op. & Gr. & Mat. & Op. \\
\hline Atlas & 0.54 & 0.05 & 0.00 & 0.41 & 0.01 & 0.00 & 0.80 & 0.00 & 0.38 & 1.75 & 0.06 & 0.38 \\
\hline European larch & 0.51 & 0.13 & 0.07 & 0.37 & 0.08 & 0.00 & 0.94 & 0.90 & 0.72 & 1.82 & 1.10 & 0.79 \\
\hline Norway spruce & 0.66 & 0.38 & 0.26 & 0.48 & 0.33 & 0.17 & 0.93 & 0.94 & 0.95 & 2.06 & 1.65 & 1.39 \\
\hline Iountai & 0.59 & 0.10 & 0.06 & 0.39 & 0.04 & 0.03 & .96 & 0.72 & 0.83 & 1.94 & 0.87 & 0.92 \\
\hline Black pine & 0.55 & 0.08 & 0.00 & 0.38 & 0.04 & 0.01 & 0.87 & 0.51 & 0.31 & 1.80 & 0.64 & 0.32 \\
\hline Scots pine & 0.26 & 0.08 & 0.04 & 0.21 & 0.04 & 0.03 & 0.19 & 0.71 & 0.78 & 0.66 & 0.83 & 0.85 \\
\hline Himalayan pine & 0.37 & 0.07 & 0.01 & 0.25 & 0.03 & 0.00 & 0.75 & 0.40 & 0.19 & 1.36 & 0.51 & 0.20 \\
\hline Eastern & 1.00 & 0.33 & 0 & 0.67 & 0.30 & 0.02 & 96 & 2 & .84 & 2.63 & 1.54 & 0.88 \\
\hline Lawson cyp & 0.83 & 0.09 & 0.06 & 0.60 & 0.04 & 0.03 & 0.97 & 0.79 & 0.69 & 2.40 & 0.92 & 0.79 \\
\hline Bald cypress & 0.43 & 0.30 & 0.15 & 0.38 & 0.32 & 0.27 & 0.95 & 0.90 & 0.89 & 1.75 & 1.52 & 1.31 \\
\hline Northern white-cedar & 0.58 & 0.22 & 0.16 & 0.51 & 0.32 & 0.11 & 0.93 & 0.94 & 0.96 & 2.02 & 1.49 & 1.22 \\
\hline Dawn redwood & 0.71 & 0.56 & 0.35 & 0.88 & 1 & 0.40 & 0.98 & 1.00 & 0.97 & 2.56 & 2.56 & 1.75 \\
\hline Chinese arborvitae & 0.66 & 0.49 & 0.41 & 0.52 & 0.62 & 0.20 & 0.94 & 0.87 & 0.85 & 2.13 & 1.98 & 1.46 \\
\hline Japanese cedar & 0.83 & 0.45 & 0.34 & 0.40 & 0.26 & 0.14 & 0.93 & 0.93 & 0.84 & 2.16 & 1.64 & 1.32 \\
\hline China fir & 0.57 & 0.19 & 0.19 & 0.45 & 0.24 & 0.12 & 0.95 & 0.89 & 0.92 & 1.96 & 1.32 & 1.23 \\
\hline Jestern hemlock & 0.55 & 0.16 & 0.02 & 0.39 & 0.19 & 0.01 & 0.92 & 0.87 & 0.57 & 1.85 & 1.22 & 0.60 \\
\hline
\end{tabular}

1: Total polyphenol content

2: Ferric reducing antioxidant power

3: 2,2-diphenyl-1-picrylhydrazyl

Gr.: green cones, Mat.: mature cones, Op.: opened cones

\subsection{HPLC-MS/MS analyses}

The identification of the molecular structure of the extractives in the cone extract solutions of Norway spruce and eastern hemlock has been accomplished using high-performance liquid chromatography/tandem mass spectrometry. Figure 1. depicts the HPLC chromatograms and Table 3 includes the major compounds found in the extracts.

Altogether 82 compounds have been described and tentatively identified by tandem mass spectrometric fragmentation (MS/MS) data. The composition of the green cones of the two taxa is different, with both including low amounts of (+)-catechin (3), (-)-epicatechin (7), and procyanidin B dimers $(1,2,4)$. Extracts included a large number of coumaric acid derivatives and flavonoid glycosides, yet not all of the compounds were found in both samples. 
Quercetin- $O$-hexosides $(18,19)$ and taxifolin- $O$-hexosides $(12,13)$ were found in both taxa; however, the pentose conjugate of quercetin (21) was only indicated in eastern hemlock. Interestingly, isorhamnetin- $O$-hexosides $(27,28)$ were only found in Norway spruce. The most abundant class of flavonoid conjugates were the kaempferol derivatives (mostly glycosides) with a total count of 10 compounds. Out of these compounds only kaempferol- $O$-hexoside (25), kaempferol- $O$-ruinoside (37) and kaempferol-rhamnose-hexose-rhamnose (50) were detected in the green cones of both taxa. The $O$-rutinosode (24), $O$-pentoside $(29,30,31), O$-rhamnoside (33), acetyl-hexoside (34), and an unknown derivative (46) of kaempferol were exclusively detected in eastern hemlock. Regarding flavonoid gylcosides, the presence of acylated kaempferol conjugates (e.g. 34) are especially interesting as these types of compounds were shown to have excellent antioxidant properties and to contribute significantly to antibacterial effects of plant extracts (Mellou et al. 2005), which highlights the importance in finding matrices with high content of acylated flavonols (García-Villalba et al. 2017).

The presence of coumaric acid as part of the compounds was evidenced by the simultaneous presence of the 163, 145, and $119 \mathrm{~m} / \mathrm{z}$ ions in the MS/MS spectra of the compounds corresponding to the $[\mathrm{M}-\mathrm{H}]^{-},\left[\mathrm{M}-\mathrm{H}_{2} \mathrm{O}-\mathrm{H}\right]^{-}$and $\left[\mathrm{M}-\mathrm{CO}_{2}-\mathrm{H}\right]^{-}$fragment ions, with $\mathrm{M}$ representing coumaric acid molecule. The structure of coumaric acid derivatives are often left unidentified using ion trap or triple quadrupole mass spectrometers (Spínola et al. 2016, Llorent-Martínez et al. 2019), as the $\mathrm{MS}^{\mathrm{n}}$ mass spectra are only suitable to indicate characteristic fragments and losses during the fragmentation process of the molecules, justifying the simultaneous presence of the coumaric acid fragments at 119,145 and $163 \mathrm{~m} / \mathrm{z}$. A more precise and informative analysis of the structure of these compounds could be conducted in the future with the use of TOF (time-of-flight) mass spectrometry by determining accurate mass of the compounds (Vilhena et al. 2020). Coumaric acid derivatives 47, 48, 49, 59, and 66 were only indicated in Norway spruce, while compounds 55, 60, and 65 were found exclusively in eastern hemlock and compound 51 in the green cone extracts of both taxa.

Piceatannol isomers $(15,16)$ and their $O$-hexoside conjugates (possibly astringin isomers, $10,11)$ were evidenced from spruce samples only.

Chlorogenic acid isomers $(5,6)$ were only found in eastern hemlock. Other compounds were left unidentified only with MS/MS data for future identification of their structure.

According to Table 3 and comparing peak heights in Figure 1, the most abundant compounds in the green cone extract of Norway spruce were astringin isomers $(10,11)$, unidentified compounds $8,58,68,69,70$ and coumaric acid derivative 51, while in eastern hemlock they were chlorogenic acid isomers 5, 6, kaempferol-rhamnose-hexose-rhamnose 50, and unidentified compounds 68, 69, 70, and 79. 

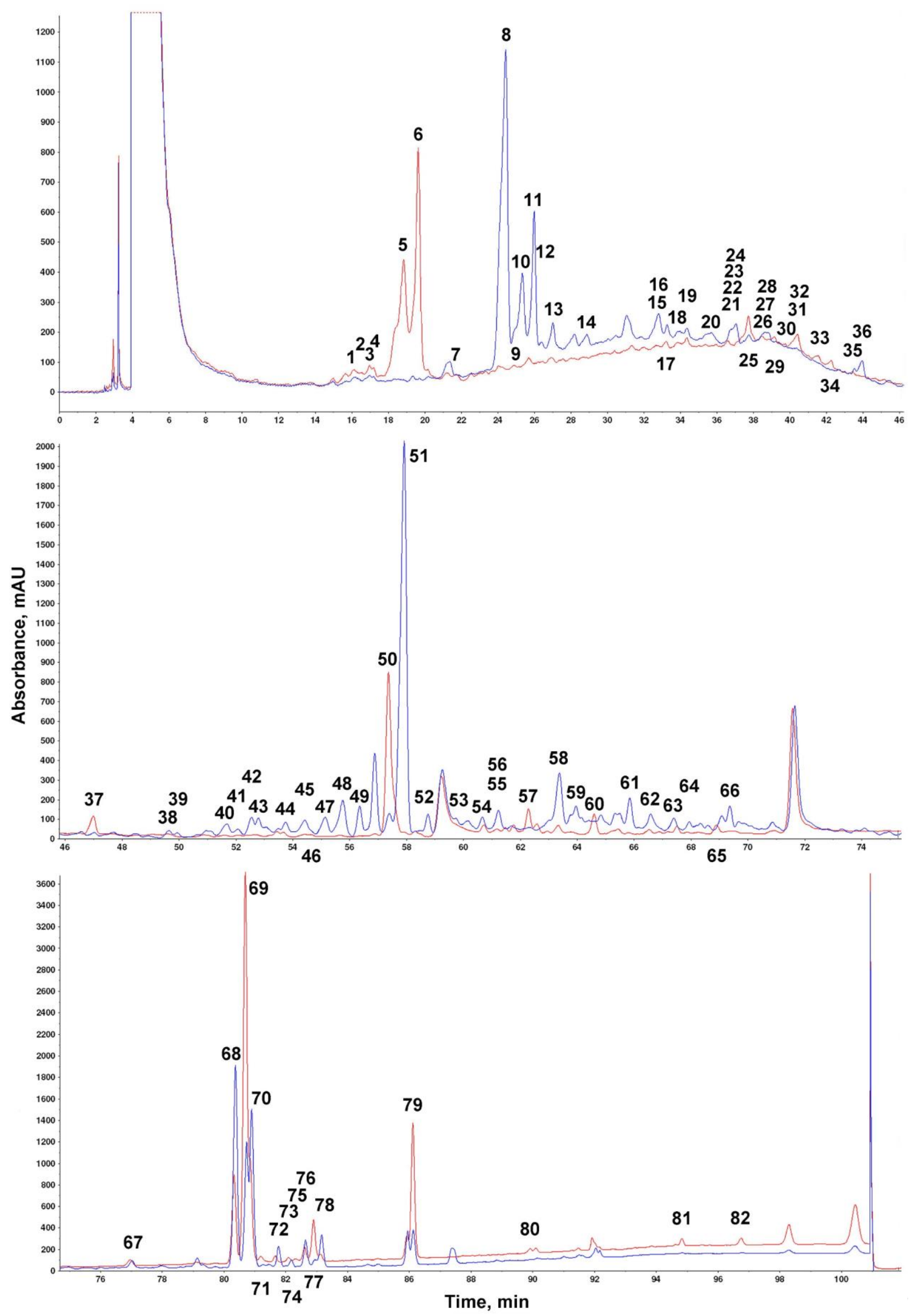

Figure 1. The PDA (250-380 $\mathrm{nm})$ chromatogram of the green cone extracts of Norway spruce (blue) and eastern hemlock (red). 
Table 3. Tentative chromatographic/mass spectrometric identification of the polyphenols in the green cones of Norway spruce $(S)$ and eastern hemlock $(H)$

\begin{tabular}{|c|c|c|c|c|c|c|}
\hline Peak & $\begin{array}{c}\mathrm{t}_{\mathrm{r}} \\
(\mathrm{min})\end{array}$ & Compound & $\mathrm{S}$ & $\mathrm{H}$ & $\begin{array}{c}{[\mathrm{M}-\mathrm{H}]^{-}} \\
\mathrm{m} / \mathrm{z}\end{array}$ & $\begin{array}{c}\mathrm{MS} / \mathrm{MS} \\
\mathrm{m} / \mathrm{z}\end{array}$ \\
\hline 1 & 15.8 & Procyanidin B dimer & $\mathrm{x}$ & $\mathrm{x}$ & 577 & $425,407,289,245,125$ \\
\hline 2 & 16.2 & Procyanidin B dimer & $\mathrm{x}$ & $\mathrm{x}$ & 577 & $425,407,289,245,125$ \\
\hline 3 & 17.0 & $(+)$-Catechin & $\mathrm{x}$ & $\mathrm{x}$ & 289 & $245,203,125,123,109$ \\
\hline 4 & 17.2 & Procyanidin B dimer & $\mathrm{x}$ & $\mathrm{x}$ & 577 & $425,407,289,245,125$ \\
\hline 5 & 18.9 & Chlorogenic acid isomer & & $\mathrm{x}$ & 353 & $191,179,161,135$ \\
\hline 6 & 19.7 & Chlorogenic acid isomer & & $\mathrm{x}$ & 353 & $191,179,161,135$ \\
\hline 7 & 21.7 & $(-)$-Epicatechin & $\mathrm{x}$ & $\mathrm{x}$ & 289 & $245,203,125,123,109$ \\
\hline 8 & 24.0 & Unidentified & $\mathrm{x}$ & & no ion & no negative ions \\
\hline 9 & 25.0 & Unidentified & $\mathrm{x}$ & & no ion & no negative ions \\
\hline 10 & 25.3 & Piceatannol- $O$-hexoside (astringin) & $\mathrm{x}$ & & 405 & $243,225,201$ \\
\hline 11 & 26.0 & Piceatannol- $O$-hexoside (astringin) & $\mathrm{x}$ & & 405 & $243,225,201$ \\
\hline 12 & 26.3 & Taxifolin- $O$-hexoside & $\mathrm{x}$ & $\mathrm{x}$ & 465 & $447,437,303,285,259,217,179,125$ \\
\hline 13 & 27.1 & Taxifolin- $O$-hexoside & $\mathrm{x}$ & $\mathrm{x}$ & 465 & $447,437,303,285,259,217,179,125$ \\
\hline 14 & 29.0 & Unidentified & $\mathrm{x}$ & & 285 & $241,217,199$ \\
\hline 15 & 32.6 & Piceatannol & $\mathrm{x}$ & & 243 & $225,201,175,174$ \\
\hline 16 & 32.8 & Piceatannol & $\mathrm{x}$ & & 243 & $225,201,175,174$ \\
\hline 17 & 33.3 & Unidentified & $\mathrm{x}$ & & 257 & 241,211 , \\
\hline 18 & 33.9 & Quercetin- $O$-hexoside & $\mathrm{x}$ & $\mathrm{x}$ & 463 & $301,300,271,255,179$ \\
\hline 19 & 34.4 & Quercetin- $O$-hexoside & $\mathrm{x}$ & $\mathrm{x}$ & 463 & $301,300,271,255,179$ \\
\hline 20 & 35.4 & Unidentified & $\mathrm{x}$ & & 359 & $341,311,297,282,195,163,145$ \\
\hline 21 & 36.6 & Quercetin- $O$-pentoside & & $\mathrm{x}$ & 433 & $301,300,271,255,243,179$ \\
\hline 22 & 36.8 & Unidentified & $\mathrm{x}$ & & 373 & $358,313,305$ \\
\hline 23 & 37.0 & Unidentified & $\mathrm{x}$ & & 359 & $341,311,297,282,195,163,145$ \\
\hline 24 & 37.2 & Kaempferol- $O$-rutinoside & & $\mathrm{x}$ & 593 & $447,285,284,255,227$ \\
\hline 25 & 37.7 & Kaemperfol- $O$-hexoside & $\mathrm{x}$ & $\mathrm{x}$ & 447 & $285,284,255,227$ \\
\hline 26 & 38.2 & Unidentified- $O$-hexoside & & $\mathrm{x}$ & 431 & 268,269 \\
\hline 27 & 38.6 & Isorhamnetin- $O$-hexoside & $\mathrm{x}$ & & 477 & $315,314,300,299,271$ \\
\hline 28 & 38.9 & Isorhamnetin- $O$-hexoside & $\mathrm{x}$ & & 477 & $315,314,300,299,271$ \\
\hline 29 & 39.2 & Kaemperfol- $O$-pentoside & & $\mathrm{x}$ & 417 & $285,284,255,227$ \\
\hline 30 & 39.8 & Kaemperfol- $O$-pentoside & & $\mathrm{x}$ & 417 & $285,284,255,227$ \\
\hline 31 & 40.4 & Kaemperfol- $O$-pentoside & & $\mathrm{x}$ & 417 & $285,284,255,227$ \\
\hline 32 & 40.5 & Unidentified- $O$-hexoside & $\mathrm{x}$ & $\mathrm{x}$ & 447 & $315,285,217,199$ \\
\hline 33 & 41.6 & Kaempferol- $O$-rhamnoside & & $\mathrm{x}$ & 431 & $285,284,255,277$ \\
\hline 34 & 42.2 & Kaempferol-acetyl-hexoside & & $\mathrm{x}$ & 489 & $429,285,284,255,227$ \\
\hline 35 & 43.6 & Unidentified & $\mathrm{x}$ & $\mathrm{x}$ & 351 & $333,315,275,251$ \\
\hline 36 & 43.9 & Unidentified & $\mathrm{x}$ & & 291 & 245,175 \\
\hline 37 & 47.0 & Kaempferol- $O$-rutinoside & $\mathrm{x}$ & $\mathrm{x}$ & 593 & $447,285,284,255,227$ \\
\hline 38 & 49.8 & Unidentified & $\mathrm{x}$ & $\mathrm{x}$ & 351 & $333,315,275,251$ \\
\hline 39 & 50.0 & Unidentified & $\mathrm{x}$ & & 367 & $349,321,247$ \\
\hline 40 & 51.7 & Unidentified & $\mathrm{x}$ & & 377 & 331 \\
\hline 41 & 52.0 & Unidentified & $\mathrm{x}$ & & 331 & $313,273,241,185$ \\
\hline 42 & 52.6 & Unidentified & $\mathrm{x}$ & & 349 & $331,287,251,244,207,189,163$ \\
\hline 43 & 52.8 & Unidentified & $\mathrm{x}$ & & 405 & $375,337,327,275$ \\
\hline 44 & 53.7 & Unidentified & $\mathrm{x}$ & & 401 & $333,315,257$ \\
\hline 45 & 54.4 & Unidentified & $\mathrm{x}$ & & 521 & $179,162,146,135$ \\
\hline 46 & 54.7 & Kaempferol derivative & & $\mathrm{x}$ & 635 & 285,284 \\
\hline 47 & 55.1 & Coumaric acid derivative & $\mathrm{x}$ & & 445 & $427,397,349,277,251,163,145,119$ \\
\hline 48 & 55.8 & Coumaric acid derivative & $\mathrm{x}$ & & 475 & $457,427,281,163,145,119$ \\
\hline 49 & 56.4 & Coumaric acid derivative & $\mathrm{x}$ & & 505 & $487,457,311,163,145,119$ \\
\hline 50 & 57.4 & Kaempferol-rhamn.-hex.-rhamn. & $\mathrm{x}$ & $\mathrm{x}$ & 739 & $593,453,285,284,255,229$ \\
\hline
\end{tabular}


Table 3 cont. Tentative chromatographic/mass spectrometric identification of the polyphenols in the green cones of Norway spruce $(S)$ and eastern hemlock $(H)$

\begin{tabular}{|c|c|c|c|c|c|c|}
\hline Peak & $\begin{array}{c}\mathrm{t}_{\mathrm{r}} \\
(\mathrm{min})\end{array}$ & Compound & $\mathrm{S}$ & $\mathrm{H}$ & $\begin{array}{c}{[\mathrm{M}-\mathrm{H}]^{-}} \\
\mathrm{m} / \mathrm{z}\end{array}$ & $\begin{array}{c}\mathrm{MS} / \mathrm{MS} \\
\mathrm{m} / \mathrm{z}\end{array}$ \\
\hline$\overline{51}$ & 58.0 & Coumaric acid derivative & $\mathrm{x}$ & $\mathrm{x}$ & 505 & $491,477,342,327,312,177,163,119$ \\
\hline 52 & 58.8 & Unidentified & $\mathrm{x}$ & & 535 & $520,491,341,326,193,179,134$ \\
\hline 53 & 59.7 & Unidentified & $\mathrm{x}$ & $\mathrm{x}$ & 445 & $417,399,315$ \\
\hline 54 & 60.7 & Unidentified & $\mathrm{x}$ & $\mathrm{x}$ & 401 & $333,315,289,245$ \\
\hline 55 & 61.1 & Coumaric acid derivative & & $\mathrm{x}$ & 549 & $489,353,311,163,145,119$ \\
\hline 56 & 61.2 & Unidentified & $\mathrm{x}$ & & 349 & $331,289,245$ \\
\hline 57 & 62.1 & Unidentified & $\mathrm{x}$ & $\mathrm{x}$ & 399 & $367,331,299$ \\
\hline 58 & 63.4 & Unidentified & $\mathrm{x}$ & $\mathrm{x}$ & 385 & $317,299,253$ \\
\hline 59 & 64.0 & Coumaric acid derivative & $\mathrm{x}$ & & 667 & $521,403,323,163,145,119$ \\
\hline 60 & 64.6 & Coumaric acid derivative & & $\mathrm{x}$ & 653 & $638,507,489,353,329,177,163,145,119$ \\
\hline 61 & 66.0 & Unidentified & $\mathrm{x}$ & & 383 & $355,315,297$ \\
\hline 62 & 66.6 & Unidentified & $\mathrm{x}$ & & 383 & $315,299,269$ \\
\hline 63 & 67.4 & Unidentified & $\mathrm{x}$ & & 471 & $425,403,353,325,285$ \\
\hline 64 & 68.0 & Unidentified & $\mathrm{x}$ & $\mathrm{x}$ & 381 & 313,269 \\
\hline 65 & 68.9 & Coumaric acid derivative & & $\mathrm{x}$ & 651 & $487,472,341,326,266,163,145,119$ \\
\hline 66 & 69.4 & Coumaric acid derivative & $\mathrm{x}$ & & 649 & $441,426,411,321,291,253,163,145,119$ \\
\hline 67 & 77.0 & Unidentified & $\mathrm{x}$ & $\mathrm{x}$ & 429 & $381,299,265$ \\
\hline 68 & 80.4 & Unidentified & $\mathrm{x}$ & $\mathrm{x}$ & 687 & 657,301 \\
\hline 69 & 80.7 & Unidentified & $\mathrm{x}$ & $\mathrm{x}$ & 397 & 301 \\
\hline 70 & 80.9 & Unidentified & $\mathrm{x}$ & $\mathrm{x}$ & 431 & $401,383,301$ \\
\hline 71 & 81.2 & Unidentified & & $\mathrm{x}$ & 469 & $425,410,384,367,339,285$ \\
\hline 72 & 81.7 & Unidentified & $\mathrm{x}$ & & 455 & $409,391,387,355,287$ \\
\hline 73 & 82.1 & Unidentified & & $\mathrm{x}$ & 957 & $467,423,381$ \\
\hline 74 & 82.2 & Unidentified & $\mathrm{x}$ & & 455 & $409,391,387,355,287$ \\
\hline 75 & 82.4 & Unidentified & & $\mathrm{x}$ & 935 & $467,424,382,265$ \\
\hline 76 & 82.6 & Unidentified & $\mathrm{x}$ & $\mathrm{x}$ & 721 & $417,335,317$ \\
\hline 77 & 82.9 & Unidentified & & $\mathrm{x}$ & 467 & $449,423,408,382,338$ \\
\hline 78 & 83.1 & Unidentified & $\mathrm{x}$ & $\mathrm{x}$ & 633 & $333,317,315,299$ \\
\hline 79 & 86.1 & Unidentified & & $\mathrm{x}$ & 635 & $591,333,317,301,271$ \\
\hline 80 & 89.9 & Unidentified & & $\mathrm{x}$ & 769 & $725,467,301$ \\
\hline 81 & 94.8 & Unidentified & & $\mathrm{x}$ & 501 & 486 \\
\hline 82 & 96.7 & Unidentified & & $\mathrm{x}$ & 529 & 514 \\
\hline
\end{tabular}

rhamn.: rhamnose; hex,:: hexose

\section{CONCLUSIONS}

The present study compared and evaluated the antioxidant capacity of the cone extracts of 16 selected coniferous taxa. The overall antioxidant power was determined by a scoring system that combined the results of the three antioxidant assays used in the study. The best antioxidant properties were determined for green cones, followed by mature and opened cones for each taxon. The highest scores were found for Tsuga canadensis, Metasequoia glyptostroboides, Chamaecyparis lawsoniana, Cryptomeria japonica, Thuja orientalis and Picea abies, which contained high amounts of antioxidants in both green and mature cones. The high-performance liquid chromatographic/tandem mass spectrometric profiling of the green cone extractives of Picea abies and Tsuga canadensis was carried out and overall 82 compounds have been tentatively identified from these samples for the first time, including kaempferol-, taxifolin-, quercetin- and isorhamnetin- $O$-glycosides, coumaric acid derivatives, chlorogenic acids, 
piceatannol and its conjugates, and flavan-3-ol compounds. Presented chromatographic/mass spectrometric data on the polyphenolic composition of the green cone extracts contributes to the determination of the structure of unidentified compounds and to the research on the role of extractives in determining the bioactivity of cone extracts. To enhance practical use of this study's results, future research will focus on the antibacterial and antifungal properties of the investigated cone extracts with the highest antioxidant capacity.

Acknowledgements: This article was made in frame of the "EFOP-3.4.3-16-00022 'QUALITAS' Development of Higher Education in Sopron, Szombathely, and Tata" and was supported by the János Bolyai Research Scholarship of the Hungarian Academy of Sciences.

\section{REFERENCES}

ANISZEWSKA, M. - BEREZA, B. (2014): Analysis of water absorption process in the cones of common pine (Pinus sylvestris L.). Ann. Wars. Univ. Life Sci.-SGGW Agric. 63: 105-112.

APAK, R. - GÜÇLÜ, K. - DEMIRATA, B. - ÖZYÜREK, M. - ÇELIK, S.E. - BEKTAŞOĞLU, B. - BERKER, K.I. - ÖZYURT, D. (2007): Comparative evaluation of various total antioxidant capacity assays applied to phenolic compounds with the CUPRAC assay. Molecules 12: 1496-1547. https://doi.org/10.3390/12071496

Auders, A.G. - SPICER, D.P. (2012): Royal Horticultural Society Encyclopedia of Conifers. A Comprehensive Guide to Cultivars and Species. Kingsblue Publishing Limited, Nicosia, Cyprus.

BAJPAI, V.K. - BAEK, K.-H. - KANG, S. C. (2017): Antioxidant and free radical scavenging activities of taxoquinone, a diterpenoid isolated from Metasequoia glyptostroboides. South African Journal of Botany 111:93-98. https://doi.org/10.1016/j.sajb.2017.03.004

BAJPAI, V.K. - RAHMAN, A. - KANG, S. C. (2007): Chemical composition and anti-fungal properties of the essential oil and crude extracts of Metasequoia glyptostroboides Miki ex Hu. Industrial Crops and Products 26: 28-35. https://doi.org/10.1016/j.indcrop.2006.12.012

BAJPAI, V.K. - SHARMA, A. - KANG, S.C. - BAEK, K.H. (2014): Antioxidant, lipid peroxidation inhibition and free radical scavenging efficacy of a diterpenoid compound sugiol isolated from Metasequoia glyptostroboides. Asian Pac. J. Trop. Med. 7: 9-15. https://doi.org/10.1016/S1995-7645(13)60183-2

BAJPAI, V.K. - YOON, J.I. - KANG, S. C. (2009): Antioxidant and antidermatophytic activities of essential oil and extracts of Metasequoia glyptostroboides Miki ex Hu. Food and Chemical Toxicology 47: 1355-1361. https://doi.org/10.1016/j.fct.2009.03.011

BENZIE, I.F.F. - STRAIN, J.J. (1996): The ferric reducing ability of plasma (FRAP) as a measure of antioxidant power: the FRAP assay. Anal. Biochem. 239: 70-76. https://doi.org/10.1006/abio.1996.0292

BourAS, M. - GRIMI, N. - BALS, O. - VOROBIEV, E. (2016): Impact of pulsed electric fields on polyphenols extraction from Norway spruce bark. Ind. Crop. Prod. 80: 50-58. https://doi.org/10.1016/j.indcrop.2015.10.051

BRADLEY, W.G. - HOLM, K.N. - TANAKA, A. (2014): An orally active immune adjuvant prepared from cones of Pinus sylvestris, enhances the proliferative phase of a primary $\mathrm{T}$ cell response. BMC Complement. Altern. Med. 14:163. https://doi.org/10.1186/1472-6882-14-163

Clark, J.T. - FEI, S. - LIANG, L. - RIESKE, R.K. (2012): Mapping eastern hemlock: Comparing classification techniques to evaluate susceptibility of a fragmented and valued resource to an exotic invader, the hemlock woolly adelgid. Forest Ecology and Management 266: 216-222. https://doi.org/10.1016/j.foreco.2011.11.030

CORNELli, U. (2009): Antioxidant use in nutraceuticals. Clin. Dermatol. 27: 175-194. https://doi.org/10.1016/j.clindermatol.2008.01.010

Coté, J. - Caillet, S. - Doyon, G. - Dussault, D. - Sylvain, J.F. - LacroiX, M. (2011): Antimicrobial effect of cranberry juice and extracts. Food Control 22: 1413-1418. https://doi.org/10.1016/j.foodcont.2011.02.024

DEDRIE, M. - JACQUET, N. - BOMBECK, P.L. - HÉBERT, J. (2015): Oak barks as raw materials for the extraction of polyphenols for the chemical and pharmaceutical sectors: A regional case study. Ind. Crop. Prod. 70: 316-321. https://doi.org/10.1016/j.indcrop.2015.03.071 
Djouahri, A. - SaKa, B. - Boudarene, L. - Benseradj, F. - Aberrane, S. - Aitmoussa, S. Chelghoum, C. - LAmari, L. - SABAou, N. - BAaliouamer, A. (2014): In vitro synergistic/antagonistic antibacterial and anti-inflammatory effect of various extracts/essential oil from cones of Tetraclinis articulata (Vahl) Masters with antibiotic and anti-inflammatory agents. Ind. Crop. Prod. 56: 60-66. https://doi.org/10.1016/j.indcrop.2014.02.035

Dzialo, M. - MierziaK, J. - KorZUn, U. - Preisner, M. - SZOPA, J. - KUlMA, A. (2016): The potential of plant phenolics in prevention and therapy of skin disorders. Int. J. Mol. Sci. 17: 1-41. https://doi.org/10.3390/ijms17020160

Everette, J. D. - Bryant, Q. M. - Green, A. M. - AbBey, Y. A. - WANGila, G. W. - WAKeR, R.B. (2010): Thorough study of reactivity of various compound classes toward the Folin-Ciocalteu reagent. J. Agric. Food Chem. 14: 8139-8144. https://doi.org/10.1021/jf1005935

FAHIMIRADA, S. - AJALloueian, F. - GHORBANPOUR, M. (2019): Synthesis and therapeutic potential of silver nanomaterials derived from plant extracts. Ecotox. Environ. Safe. 168: 260-278. https://doi.org/10.1016/j.ecoenv.2018.10.017

Frydman, A. - Weisshaus, O. - HuhMAN, D.V. - Sumner, L.W. - BAR-PELED, M. - LeWinsohn, E. - ET AL. (2005): Metabolic engineering of plant cells for biotransformation of hesperedin into neohesperidin, a substrate for production of the low-calorie sweetener and flavor enhancer NHDC. J Agric. Food Chem. 53: 9708-9712. https://doi.org/10.1021/jf051509m

GarcíA-Villalba, R. - ESPín, J.C. - TOMÁs-BARBERÁN, F.A. - ROCHA-GUZMÁN, N.E. (2017): Comprehensive characterization by LC-DAD-MS/MS of the phenolic composition of seven Quercus leaf teas. Journal of Food Composition and Analysis 63: 38-46. https://doi.org/10.1016/j.jfca.2017.07.034

GENDEK, A. - ANISZEWSKA, M. - MALAŤÁK, J. - VELEBIL, J. (2018): Evaluation of selected physical and mechanical properties of briquettes produced from cones of three coniferous tree species. Biomass Bioenerg. 117: 173-179. https://doi.org/10.1016/j.biombioe.2018.07.025

GHISElli, A. - SERAFINI, M. - NATELlA, F. - SCACCINI, C. (2000): Total antioxidant capacity as a tool to assess redox status: critical view and experimental data. Free Radic. Biol. Med. 29: 1106-1114. https://doi.org/10.1016/S0891-5849(00)00394-4

GYAWALI, R. - IBRAHIM, S.A. (2014): Natural products as antimicrobial agents. Food Control 46: 412 429. https://doi.org/10.1016/j.foodcont.2014.05.047

HERNES, P.J. - HEDGES, J.I. (2004): Tannin signature of barks, needles, leaves, cones, and wood at the molecular level. Geochim. Cosmochim. Ac. 68: 1293-1307. https://doi.org/10.1016/j.gca.2003.09.015

HOFMANN, T. - VISI-RAJCZI, E. - ALBERT, L. (2020): Antioxidant properties assessment of the cones of conifers through the combined evaluation of multiple antioxidant assays. Industrial Crops and Products 145: 111935. https://doi.org/10.1016/j.indcrop.2019.111935

Horiba, H. - Nakagawa, T. - Zhu, Q. - Ashour, A. - Watanabe, A. - Shimizu, K. (2016): Biological activities of extracts from different Parts of Cryptomeria japonica. Natural Product Communications 11 (9): 1337-1342. https://doi.org/10.1177/1934578X1601100939

HUSSAIN, S. - GHOURI, A.S. - AHMAD, A. (2019): Pine cone extract as natural coagulant for purification of turbid water. Heliyon 5 (3): e01420. https://doi.org/10.1016/j.heliyon.2019.e01420

KARTAL, E. - OZTURK, S. (2016): Pine cone as an alternative dietary fiber source and its effects on cake and cookie quality. GIDA/The Journal of Food 41 (5): 291-297. https://doi.org/10.15237/gida.GD16016

KEMERLi-KALBARAN, T. - OZDEMIR, M. (2019): Multi-response optimization of oil extraction from pine nut (Pinus pinea L.) by response surface methodology: Extraction efficiency, physicochemical properties and antioxidant activity. LWT-Food Sci. Technol. 103: 34-43. https://doi.org/10.1016/j.lwt.2018.12.067

Kilinc, M. - Canbolat, S. - Merdan, N. - Dayioglu, H. - AKin, F. (2015): Investigation of the color, fastness and antimicrobial properties of wool fabrics dyed with the natural dye extracted from the cone of Chamaecyparis lawsoniana. Procedia - Social and Behavioral Sciences 195: 2152-2159. https://doi.org/10.1016/j.sbspro.2015.06.281

KobUs-CisowsKA, J. - FlACZYK, E. - RUDZIŃSKA, M. - KMIECIK, D. (2014): Antioxidant properties of extracts from Ginkgo biloba leaves in meatballs. Meat Sci. 97: 174-180.

https://doi.org/10.1016/j.meatsci.2014.01.011 
KuPETA, A.J.K. - NAIDOO, E.B. - OfOMAJA, A.E. (2018): Kinetics and equilibrium study of 2-nitrophenol adsorption onto polyurethane cross-linked pine cone biomass. J. Clean. Prod. 179: 191-209. https://doi.org/10.1016/j.jclepro.2018.01.034

LAMEdiCA, S. - LingUA E. - POPA, I. - MOTTA, R. - CARRER, M. (2011): Spatial structure in four Norway spruce stands with different management history in the Alps and Carpathians. Silva Fenn. 45: 865-873. https://doi.org/10.14214/sf.75

LESJAK, M.M. - BEARA, I.N. - ORČIĆ, D.Z. - ANAČKOV, G.T. - BALOG, K.J. - FRANCIŠKOVIĆ, M.M. MIMICA-DuKIĆ, N.M. (2011): Juniperus sibirica Burgsdorf. as a novel source of antioxidant and anti-inflammatory agents. Food Chem. 124: 850-856. https://doi.org/10.1016/j.foodchem.2010.07.006

LESJAK, M.M. - BEARA, I.N. - ORČIĆ, D.Z. - KNEŽEVIĆ, N.P. - SIMIN, N.Đ. - SVIRČEV, Đ.E. - MIMICADUKIĆ, N.M. (2014): Phytochemical composition and antioxidant, anti-inflammatory and antimicrobial activities of Juniperus macrocarpa Sibth. et Sm. J. Funct. Foods 7: 257-268. https://doi.org/10.1016/j.jff.2014.02.003

Llorent-MARTínez, E.J. - FernÁNDEZ-DE CóRdova, M. L. - Zengin, G. - BAHADORI, M. B. AumeERUdDY, M.Z. - RENGASAMY, K.R.R. - MAHOMOODALly, M. F. (2019): Parentucellia latifolia subsp. latifolia: A potential source for loganiniridoids by HPLC-ESI-MS ${ }^{\mathrm{n}}$ technique. Journal of Pharmaceutical and Biomedical Analysis 165: 374-380. https://doi.org/10.1016/j.jpba.2018.12.025

MANACH, C. - SCALBERT, A. - MORAND, C. - RÉMÉSY, C. - JiMÉNEZ, L. (2004): Polyphenols: food sources and bioavailability. Am. J. Clin. Nutr. 79: 727-747. https://doi.org/10.1093/ajcn/79.5.727

MCLAFFERTY, F.W. - TUREČEK, F. (1993): Interpretation of Mass Spectra. University Science Books, Mill Valley.

MCWILLIAMS, W.H. - SCHMIDT, T.L. (2000): Composition, structure, and sustainability of hemlock ecosystems in eastern North America. In: K.A. McManus, K.S. Shields, D.R. Souto (Eds.), Proceedings: Symposium on Sustainable Management of Hemlock Ecosystems in Eastern North America, USDA Forest Service Northeastern Forest Experiment Station General Technical Report NE-267, Newtown Square, PA, USA (2000), pp. 5-10.

Mellou, F. - LaZARI, D. - SkaltSA, H. - Tselepis, A.D. - Kolisis, F.N. - Stamatis, H. (2005): Biocatalytic preparation of acylated derivatives of flavonoid glycosides enhances their antioxidant and antimicrobial activity. J. Biotechnol. 116: 295-304.

https://doi.org/10.1016/j.jbiotec.2004.12.002

MELONI, M. - PERINI, D. - BINELLI, G. (2007): The distribution of genetic variation in Norway spruce (Picea abies Karst.) populations in the Western Alps. J. Biogeogr. 34: 929-938. https://doi.org/10.1111/j.1365-2699.2006.01668.x

MÜLLER, L. - FRÖHLICH, K. - BÖHM, V. (2011): Comparative antioxidant activities of carotenoids measured by ferric reducing antioxidant power (FRAP), ABTS bleaching assay ( $\alpha$ TEAC), DPPH assay and peroxyl radical scavenging assay. Food Chem. 129: 139-148.

https://doi.org/10.1016/j.foodchem.2011.04.045

Mtshatsheni, K.N.G. - OfOMAJA, A.E. - NAIDOO, E.B. (2019): Synthesis and optimization of reaction variables in the preparation of pine-magnetite composite for removal of methylene blue dye. S. Afr. J. Chem. Eng. 29: 33-41. https://doi.org/10.1016/j.sajce.2019.05.002

NAGASAWA, H. - SAKAmOTO, S. - SAWAKI, K. (1992): Inhibitory effect of lignin-related pine cone extract on cell proliferating enzyme activity of spontaneous mammary tumours in mice. Anticancer Res. 12: 501-503.

NAgATA, K. - SAKAgAmi, H. - HaradA, H. - Nonoyama, M. - Ishihama, A. - KonNo, K. (1990): Inhibition of influenza virus infection by pine cone antitumor substances. Antivir. Res. 13: 11-22. https://doi.org/10.1016/0166-3542(90)90041-5

PACKER, L. - RIMBACH, G. - VIRGILI, F. (1999): Antioxidant activity and biologic properties of procyanidin-rich extract from pine (Pinus maritima) bark, pycnogenol. Free Radic. Biol. Med. 27: 704-724. https://doi.org/10.1016/S0891-5849(99)00090-8

POPA, V.I. - DUMITRU, M. - VOLF, I. - ANGHEL, N. (2008): Lignin and polyphenols as allelochemicals. Ind. Crop. Prod. 27: 144-149. https://doi.org/10.1016/j.indcrop.2007.07.019 
PRIOR, R.L. - WU, X. - SCHAICH, K. (2005): Standardized methods for the determination of antioxidant capacity and phenolics in foods and dietary supplements. J. Agric. Food. Chem. 53: 4290-4302. https://doi.org/10.1021/jf0502698

Rolim, W.R. - PELEgrino, M.T. - Lima, B.A. - FerRAZ, L.S. - CostA, F.N. - BERnARdeS, J.S. RodigueS, T. - BROCCHI, M. - SEABRA, A.B. (2019): Green tea extract mediated biogenic synthesis of silver nanoparticles: Characterization, cytotoxicity evaluation and antibacterial activity. App. Surf. Sci. 463: 66-74. https://doi.org/10.1016/j.apsusc.2018.08.203

SAWADA, Y. - NAKABAYASHI, R. - YAMADA, Y. - SUZUKI, M. - SATO, M. - SAKATA, A. - AKIYAMA, K. SAKURAI, T. - MATSUDA, F. - AOKI, T. - HIRAI, M.Y.-SAITO, K. (2012): RIKEN tandemmass spectral database (ReSpect) for phytochemicals: a plant-specificMS/MS-based data resource and database. Phytochemistry 82: 38-45. https://doi.org/10.1016/j.phytochem.2012.07.007

SHARMA, O.P. - BHAT, T.K. (2009): DPPH antioxidant assay revisited. Food Chem. 113: 1202-1205. https://doi.org/10.1016/j.foodchem.2008.08.008

SingletON, V.L. - ROSSI, J.A. (1965): Colorimetry of total phenolics with phosphomolibdicphosphotungstic acid reagents. Am. J. Enology Vitic. 161: 144-158.

Smith, E.C.J. - Williamson, E.M. - WarehaM, N. - KAAtZ, G.W. - GibBons, S. (2007): Antibacterials and modulators of bacterial resistance from the immature cones of Chamaecyparis lawsoniana. Phytochemistry 68: 210-217. https://doi.org/10.1016/j.phytochem.2006.10.001

Spínola, V. - Llorent-Martínez, E.J. - Gouveia-FigueiRA, S. - CASTiLho, P. C. (2016): Ulex europaeus: from noxious weed to source of valuable isoflavonesand flavanones. Industrial Crops and Products 90: 9-27. https://doi.org/10.1016/j.indcrop.2016.06.007

SÜNTAR, I. - TUMEN, I. - USTÜN, O. - KELES, H. - AKKOL, E.K. (2012): Appraisal on the wound healing and anti-inflammatory activities of the essential oils obtained from the cones and needles of Pinus species by in vivo and in vitro experimental models, J. Ethnopharmacol. 139: 533-540. https://doi.org/10.1016/j.jep.2011.11.045

TUMEN, I. - SENOL, F.S. - ORHAN, I.E. (2012): Evaluation of possible in vitro neurobiological effects of two varieties of Cupressus sempervirens (Mediterranean cypress) through their antioxidant and enzyme inhibition actions. Turk. J. Biochem. 37: 5-13. https://doi.org/10.5505/tjb.2012.92400

TÜMEN, I. - AKKOL, E.K. - TAŞTAN, H. - SÜNTAR, I. - KURTCA, M. (2018): Research on the antioxidant, wound healing, and anti-inflammatory activities and the phytochemical composition of maritime pine (Pinus pinaster Ait). J. Ethnopharmacol. 211: 235-246. https://doi.org/10.1016/j.jep.2017.09.009

VYVYAN, J.R. (2002): Allelochemicals as leads for new herbicides and agrochemicals. Tetrahedron 58: 1631-1646. https://doi.org/10.1016/S0040-4020(02)00052-2

VILHENA, R.O. - FIGUEIREDO, I.D. - BAVIERA, A.M. - SilVA, D.B. - MARSON, B.M. - OliVEIRA, J.A. - PeCCININI, R.G. - Borges, I.K. - Pontarolo, R. (2020): Antidiabetic activity of Musa x paradisiaca extracts in streptozotocin-induced diabetic rats and chemical characterization by HPLC-DAD-MS. Journal of Ethnopharmacology 254: 112666. https://doi.org/10.1016/j.jep.2020.112666

WANG, L. - LI, X. - WANG, H. (2019): Physicochemical properties, bioaccessibility and antioxidant activity of the polyphenols from pine cones of Pinus koraiensis. Int. J. Biol. Macromol. 126: 385391. https://doi.org/10.1016/j.ijbiomac.2018.12.145

WatANABE, K. - Momose, F. - HANDA, H. - NAGATA, K. (1995): Interaction between influenza virus proteins and pine cone antitumor substance that inhibits the virus multiplication. Biochem. Biophys. Res. Commun. 214: 318-323. https://doi.org/10.1006/bbrc.1995.2290

WATSON, R.R. - PREEDY, V.R. - ZIBADI, S. (2018): Polyphenols: Prevention and Treatment of Human Disease. Academic Press, London.

Yogesh, K. - Ali, J. (2014): Antioxidant potential of thuja (Thuja occidentalis) cones and peach (Prunus persia) seeds in raw chicken ground meat during refrigerated $\left(4 \pm 1{ }^{\circ} \mathrm{C}\right)$ storage. J. Food Sci. Technol. 51 (8): 1547-1553. https://doi.org/10.1007/s13197-012-0672-5

YOON, J.I. - BAJPAI, V.K. - KANG, S. C. (2011): Synergistic effect of nisin and cone essential oil of Metasequoia glyptostroboides Miki ex Hu against Listeria monocytogenes in milk samples. Food and Chemical Toxicology 49: 109-114. https://doi.org/10.1016/j.fct.2010.10.004 